\title{
Cytomorphological study of palpable Breast Lumps by FNAC
}

\author{
VenkataramanaBabu $\mathbf{p}^{1}$, Neeraja $\mathbf{M}^{2}$, Varalakshmi K.P ${ }^{3}$, SivasankaraNaik $\mathrm{V}^{4}$, Sumankumar T.C.S. ${ }^{5}$, \\ ${ }^{1}$ Dr. P. VenkataramanaBabu,AssociateProfessorofPathology, ${ }^{2}$ Dr. M. Neeraja, Professor of Pathology, ${ }^{3}$ Dr. K.P. \\ Varalakshmi, Associate Professor of Pathology, ${ }^{4}$ Dr.V. SivasankaraNaik, Assistant Professor of Pathology, ${ }^{5}$ Dr.T.C.S. \\ Sumankumar, Tutor of Pathology, ${ }^{6}$ Dr. C. Bhavani, AssistantProfessor of Pathology, ${ }^{7}$ Dr. P. Shravani, Assistant \\ Professor of Pathology, ${ }^{8}$ Dr. R. Sujeevaswapna,Assistant Professor of Pathology. All are affiliated with Government \\ Medical College, Anantapur\&Dr. NTR University of Health Sciences, Vijayawada, Andhra Pradesh, India.
}

AddressforCorrespondence: Dr. P.VenkataramanaBabu,Email: pvramanababu22@gmail.com

\begin{abstract}
Aim and Objective: To assess the distribution of various cytomorphological patters of clinically palpable breast lumps by Fine Needle Aspiration Cytology technique.Materials and Methods:A retrospective study over a period of 3 years 270 breast aspirates who attended the surgery outpatient department in government medical college Anantapur fromJanuary 2012 to December 2014 were studied with clinical correlation and cytological analysis with FNAC. Smears were stained with $\mathrm{H} \& \mathrm{E}$ stain, and correlation with imaging studies, including mammography was done.Results and Analysis: Total of 270 cases were studied, out of these $191(70.74 \%)$ were found benign and $50(18.51 \%)$ were malignant. $20(7.40 \%)$ cases given un- satisfactory results. Out of 270 cases of analysis, Fibroadenoma was the most common benign lesion found in $133(49.25 \%)$ patients, followed by fibrocystic disease $28(10.37 \%)$ and mastitis/Breast abscess $8(2.96 \%)$ were common breast lesions on cytology. Malignant breast lesions constitute 50(18.51\%) cases, among which Duct cell carcinoma 47(17.40\%) cases were commonest type.Conclusion: Benign breast lesions are common than malignant lesions, fibroadenoma and fibrocystic disease are more common in benign disease.Maximum number of lesions (34\%) was seen in age group of 20 to 30 years, whereas IDC accounts for the highest number of malignant lesions.Fine-needle aspiration cytology is a rapid and effective method for the primary categorization of palpable breast lumps into benign, malignant, atypical, suspicious, and unsatisfactory categories.
\end{abstract}

Keywords: Palpable, Breast Lumps, Cytomorphology, FNAC.

\section{Introduction}

Breast is an appendage of skin, breast lumps are very common complaint for women of all ages, but are particularly common during the reproductive years.Breast lumps may occur spontaneously or gradually, evaluating a breast mass can be a difficult task. It may be difficult for the patient because of the anxiety associated with her underlying fear of abreast malignancy. Majority of breast symptoms or lesions will prove to be of a benign etiology. Benign as well as malignant breast lesions are quite common in Indian population. It is the second most common cancer site after cancer cervix in Indian females.Breast carcinoma is the most common malignant neoplasm and the leading cause of death from cancer in women, with

Manuscript received: $01^{\text {st }}$ Feb 2016

Reviewed: $10^{\text {th }}$ Feb 2016

Author Corrected: $17^{\text {st }} \mathrm{Feb} 2016$

Accepted for Publication: 27 $7^{\text {st }}$ Feb 2016 detected in India yearly [2].Special tests such as more than 1million cases occurringworldwideannually [1].Currently 75,000 new cases of breast cancer are mammogram often detect breast lumps that cannot be felt. Rates of breast cancer are highest in the age group $60-64$. Only $11 \%$ of people presenting with breast lumps turn out to have breast cancer, many breast cancers are localized and can be treated effectively if diagnosed early. Some benign diseases are associated with a slightly increased risk of cancer in future, depending on that patient's medical history, family history and risk factors. The use of various investigations depends on the history and examination findings. A mammography uses low energy x-rays to image the breast. For a woman over 30 years old presenting with a new breast lump a mammogram is an appropriate first investigation. It is also used in 
screening for breast cancer to detect breast lumps that cannot be felt. While a mammogram can identify suspicious features in breast lump, it cannot determine whether a lump is benign or not. Ultrasound is an appropriate first investigation for women who are under 30 years old or pregnant and have a breast lump. It is also useful in patients with a palpable breast lump and an abnormal mammogram result. Ultrasound can demonstrate if a mass is cystic or solid and can also be used to guide aspiration (e.g. for treatment of breast cyst) or biopsy. Fine needle aspiration is minor procedure; needle inserted into the breast lump and the syringe plunger is drawn out (aspirate) to obtain a sample of cells. The tissue or fluid sample taken can be examined for the presence of any cancerous cells. FNA can also be used to treat a breast cyst, by aspirating the fluid inside the cyst itself. Core needle biopsy (CNB) is more invasive procedure than FNA in the detection of breast cancer. It uses a larger, hallow needle that allows better sampling of the tissue within the lump, which can then be examined for malignancy. The "triple test" is a combination of physical examination, breast imaging (usually mammography) and biopsy (FNA or CNB) to calculate a triple test score. The only hope of reducing morbidity/mortality due to breast cancer is in the early detection of disease. This can be achievedby"FineNeedleAspirationCytology"whichisuse d now-a-days for cytological diagnosis of various breast lesions. FNAC is not only useful in diagnosis and further planning of treatment without need for biopsy, but also helpful in prognostication of the tumor factors such as nuclear grading, mitotic index, hormone receptor status and DNA contents [3].

\section{Aim and Objectives}

To assess the distribution of various cytomorphological patters of clinically palpable breast lumps by Fine Needle Aspiration Cytology technique.

\section{MaterialsandMethods}

A retrospective study carried out at Government Medical College, Anantapur from Jan 2012 to Dec 2014 over a period of 3 years on 270 female patients with clinically palpable breast lumps which were referred to the department of pathology for FNAC of breast.Physical examination with palpation followed by Fine Needle Aspiration Cytology was done by using 23 gauge needle attached to $10 \mathrm{cc}$ disposable syringe. The sample was obtained with aspiration and non-aspiration techniques with minimum passes to minimize hemorrhage. Palpable axillary lymph nodes were aspirated to exclude metastasis. Wet fixed smears were stained with Haematoxylin and Eosin (H\&E) stain, one forPapanicolaoustain whenever necessary, data was taken regarding the age of the patient, site of involvement, size of the lesion, cytological diagnosis and presence of metastasis in case of malignancies, correlation with available imaging studies including mammography was done.

\section{ResultsandAnalysis}

A total of 270 FNAC of palpable breast lumps were done in the cytopathology department of Government Medical College Anantapur. The age of the patients in the present study varied from 17-75 years. Maximum number of lesions (34\%) was seen in age group of 20 to 30 years, followed by 30 to 40 years $(27 \%)$, and 50 to 60 years $(22 \%)$. In $>70$ years age only 2 lesions $(0.8 \%)$ were noticed (table- 1$)$.

Table 1: Distribution of lesions according to age groups

\begin{tabular}{|l|l|l|}
\hline Age group in years & Number of cases & Percentage (\%) \\
\hline$<20$ yrs. & 25 & 10 \\
\hline $21-30$ & 85 & 34 \\
\hline $31-40$ & 68 & 27 \\
\hline $51-60$ & 55 & 22 \\
\hline $61-70$ & 15 & 6 \\
\hline $71-80$ & 2 & 0.8 \\
\hline
\end{tabular}

The cytological spectrum of various breast lesions in the present study shows that out of the total 270 cases, benign lesions were $191(70.7 \%)$, atypical cases $7(2.5 \%)$, suspicious cases $2(0.7 \%)$,frankly malignant $50(18.5 \%)$, unsatisfactory 20(7.4\%)were reported (table-2). 
Table 2: Cytological spectrum of various palpable breast lesions

\begin{tabular}{|l|l|l|}
\hline Cytological type & Number of cases & Percentage (\%) \\
\hline Benign & 191 & 70.7 \\
\hline Atypical & 7 & 2.5 \\
\hline Suspicious & 2 & 0.7 \\
\hline Malignant & 50 & 18.5 \\
\hline Unsatisfactory & 20 & 7.4 \\
\hline Total & $\mathbf{2 7 0}$ & $\mathbf{1 0 0}$ \\
\hline
\end{tabular}

Total of 50 malignant breast lesions wereanalyzed. Out of 270 breast aspirates 20(7.4\%) casesyieldedinadequate aspiration material(or) diagnosis was equivocal. Out of 270 cases, benign breast lesions 191(70.74\%) were most common lesions in young females, among which fibroadenomaconstitute 133(49.25\%) cases were the commonest presentation. Among total 133 fibroadenomas , 2(1.5\%)were Giantfibroadenomas, 3 (2.2\%)cases show bilateral breast involvement, $5(3.7 \%)$ cases were located ataxillary tail of Spence.Out of 270 breast aspirates, (table-3) fibrocystic disease were $28(10.37 \%)$, benign epithelial hyperplasia were 6(2.22\%), breast abscess $8(2.96 \%)$, duct ectasia $4(1.48 \%)$, simple cyst $2(0.7 \%)$, granulomatous mastitis $2(0.7 \%)$, fat necrosis $2(0.7 \%)$, and galactocoele $2(0.7 \%)$ caseswere reported. Out of total 270 aspirates 50(18.51\%) cases were reported as malignant lesions. Among which Duct cell carcinoma constitute $47(17.40 \%)$ cases, lobular carcinoma, mucinous carcinoma and recurrent phyllodestumour each $1(0.37 \%)$ casewas reported.

Tablen3:Cytological diagnosis of breast lesions by FNAC $(\mathbf{n}=\mathbf{2 7 0})$

\begin{tabular}{|c|c|c|c|}
\hline Category & Cytologicaldiagnosis & Numberofcases & Percentage (\%) \\
\hline \multirow{11}{*}{$\begin{array}{l}\text { 1. Inflammatory and Benign } \\
\text { Lesions } \\
\text { (191 Cases-70.74\%) }\end{array}$} & Acute mastitis/abscess & 8 & 2.96 \\
\hline & Granulomatousmastitis & 2 & 0.7 \\
\hline & Fat necrosis & 2 & 0.7 \\
\hline & Duct ectasia & 4 & 1.48 \\
\hline & Fibroadenoma & 133 & 49.25 \\
\hline & Fibrocystic disease & 28 & 10.37 \\
\hline & Simple cyst & 2 & 0.7 \\
\hline & Epithelial hyperplasia & 6 & 2.22 \\
\hline & Galactocele & 2 & 0.7 \\
\hline & Benign phyllodes tumor & 2 & 0.7 \\
\hline & Papillary lesion & 2 & 0.7 \\
\hline $\begin{array}{l}\text { 2. Atypical/indeterminate- } \\
\text { probably benign }\end{array}$ & Epithelial hyperplasia with atypia & 7 & 2.59 \\
\hline $\begin{array}{l}\text { 3. Suspicious of Malignancy } \\
(02 \text { cases }-0.7 \%)\end{array}$ & Atypical cells suspicious of malignancy & 2 & 0.70 \\
\hline \multirow{4}{*}{$\begin{array}{l}\text { 4.Malignancy (50cases }-18.51 \\
\%)\end{array}$} & Ductal carcinoma & 47 & 17.40 \\
\hline & Lobular carcinoma & 1 & 0.37 \\
\hline & Mucinous carcinoma & 1 & 0.37 \\
\hline & Recurrent malignant phyllodes tumor & 1 & 0.37 \\
\hline 5. unsatisfactory & & 20 & 7.40 \\
\hline Total & & 270 & 100 \\
\hline
\end{tabular}

Out of 50 malignant cases $9(18 \%)$ presents with palpable axillary lymph nodes. Out of that, 3 cases show metastatic lymphadenitis. 
Table4: Classification of breast lesions according to size of the lesion

\begin{tabular}{|l|l|l|l|}
\hline S.No. & Size of the lump $(\mathbf{c m})$. & Number of cases & Percentage $(\%)$ \\
\hline 1. & $<5$ & 190 & 70.3 \\
\hline 2. & $5-10$ & 55 & 20.3 \\
\hline 3. & $>10$ & 25 & 9.25 \\
\hline & Total & 270 & 100 \\
\hline
\end{tabular}

Regarding size of the breast lump, maximum size $>10 \mathrm{~cm}$ in $25(9.25 \%)$ cases, minimum size $<5 \mathrm{~cm}$ in $190(70.3 \%)$ cases were noticed (table-4).

Table-5: Side wise distribution of breast lesions

\begin{tabular}{|l|l|l|l|l|l|l|}
\hline \multirow{2}{*}{ Side } & \multicolumn{4}{|l|}{ Quadrant } & Total \\
\cline { 2 - 6 } & U.O & U.I & L.O & L.I & Central & \\
\hline Right & 35 & 16 & 21 & 15 & 23 & $110(40.7)$ \\
\hline Left & 50 & 27 & 24 & 23 & 36 & $160(59.2 \%)$ \\
\hline
\end{tabular}

Regarding side wise distribution, left side was most commonly involved (59.25\%), out of that left upper outer quadrant were most commonly involved (Table-5).

Table-6: Presenting symptoms of malignant neoplastic lesions $(n=50)$

\begin{tabular}{|l|l|l|l|}
\hline S.No. & Presenting symptom & $\begin{array}{l}\text { Numberof } \\
\text { cases }\end{array}$ & Percentage (\%) \\
\hline 1. & Painless lump in the breast & 16 & 32 \\
\hline 2. & Nipple retraction & 10 & 20 \\
\hline 3. & Palpable axillary lymph nodes 2 or more & 9 & 18 \\
\hline 4. & Pain full lump & 5 & 10 \\
\hline 5. & Ulceration fungation of the mass & 4 & 8 \\
\hline 6. & Nipple discharge & 3 & 6 \\
\hline 7. & Signs and symptoms of metastasis & 3 & 6 \\
\hline
\end{tabular}

The clinical symptoms of patients presenting with suspected malignant lesion varies from painful lump (10\%) to painless mass (32\%), nipple retraction (20\%), nipple discharge (6\%) etc.(table-6).

\section{Discussion}

Breast is an easily accessible site for fine needle aspiration cytology. There is an increasing tendency to seek to confirm the diagnosis of the breast cancer at first consultation by some form of needle biopsy technique. The present series confirms the worth and clinical utility of fine needle aspiration cytology in the investigation of the patient with benign and malignant breast disease.

The present study accounted for more numbers of benign cases and less number of malignant cases, correlation with Mohammed et al.,[4]Yeoh and Cha et al.,[5]Parkand Ham et al.,[6] Rocha et al.,[7] and Dominguez et al.,[8].Incidence of suspicious, atypical lesions in the present study is almost same as that in other studies. The finding of unsatisfactory cases in the present study is more than in the study by Mohammed et al,[4]. 
Table8:comparative study ofcytologicallesions

\begin{tabular}{|l|l|l|l|l|l|l|}
\hline $\begin{array}{l}\text { Cytological } \\
\text { type }\end{array}$ & $\begin{array}{l}\text { Present } \\
\text { study(270) }\end{array}$ & $\begin{array}{l}\text { Mohammed } \\
\text { et al. (157) }\end{array}$ & $\begin{array}{l}\text { Yeoh and } \\
\text { Chan (1533) }\end{array}$ & $\begin{array}{l}\text { Park and } \\
\text { Ham (669) }\end{array}$ & $\begin{array}{l}\text { Rocha et al } \\
(\mathbf{8 0 9})\end{array}$ & $\begin{array}{l}\text { Dominguez } \\
\text { et al.(1398) }\end{array}$ \\
\hline Benign & $191(70.7 \%)$ & $112(71.3 \%)$ & $1121(73.12)$ & $384(57.4)$ & $615(76.02 \%)$ & $\begin{array}{l}1087 \\
(77.75 \%)\end{array}$ \\
\hline Atypical & $7(2.5 \%)$ & $2(1.3 \%)$ & $51(3.32 \%)$ & $24(3.6 \%)$ & ---- & ---- \\
\hline Suspicious & $2(0.7 \%)$ & $2(1.3 \%)$ & $19(1.23 \%)$ & $7(1.0 \%)$ & $26(3.21 \%)$ & $20(1.14 \%)$ \\
\hline Malignant & $50(18.5 \%)$ & $38(24.2 \%)$ & $68(4.43 \%)$ & $85(12.7 \%)$ & $97(12 \%)$ & $149(10.65 \%)$ \\
\hline Unsatisfactory & $20(7.4 \%)$ & $3(1.9 \%)$ & $274(17.83 \%)$ & $169(25.3 \%)$ & $71(8.77 \%)$ & $142(10.15 \%)$ \\
\hline
\end{tabular}

In the present study fibroadenoma $(49.25 \%)$ followed by fibrocystic disease $(10.37 \%)$ and mastitis/breast abscess (2.96\%) were the most common breast lesions on cytology, which is in agreement with Dominguez et al.,[8] (34.49\%, $32.17 \%$, and $1.55 \%$ respectively). Where as in study by Tiwari [9] and Qasim et al.,[10]fibroadenoma (56.25\% and $82.14 \%$ ) followed by mastitis/breast abscess $(20.31 \%)$ and $10.71 \%)$ and fibrocystic disease $(7.81 \%$ and $3.57 \%)$ were the most common breast lesions. In the present study 50 malignant lesions were seen. While in study by Dominguez et al.,[8]147 cases were seen. Duct cell carcinoma was most common in the present study with $47(17.40 \%)$ casesand $141(95.91 \%)$ in study by Domínguez et al.,[8]. Mucinous carcinoma, lobular carcinomas were second mostcommontumors in this study with $1(0.37 \%)$ case each,while in study by Domínguez et al.,[8] also seen in $1(0.68 \%)$ case. Lobular carcinoma was seen in only $1(0.37 \%)$ case in this study, while itwas second common tumor in study by Domínguez et al.,[8] with $4(2.72 \%)$ cases.As overall pattern of type of malignancy with IDC were accounting for $>85 \%$ cases in both studies. In the present study we reported 2 benignphyllodes and 1 recurrent malignantphyllodestumour. Zuk et al.,[11] classified all aspirates into the following groups: Inadequate: Either extremelyhypo cellular with regard to epithelial cells or bloodstained to an extent that all other elementsare obscured. Benign: Characterized by sheets of regular ductal cells with nuclear features ofbenign cells, often admixed with a large number of "stripped" nuclei. Suspicious: Hyper cellular specimen, which had an admixture of regular cells and others with abnormal nuclearand cytoplasm features falling short of a firm diagnosis of malignancy. Malignant: Hyper cellular specimen comprising cells with unequivocal cytological features of malignancy. Tabbara et al.,[12] recommended in the national comfort institute conference the use of astandardized approach for the reporting of breast FNAs. The classification system proposed atthe conference places breast FNAs into one of five categories:

1.Benign

2.Atypical/indeterminate

3.Suspicious/probably malignant

4.Malignant

5.Unsatisfactory.

In the present study, maximum numbers of cytologically benign lesions were seen in the agegroup ranging from 17 to 45 years (table-1). This was similar to the findings by Khemka et al.,[13] and Rocha et al.,[7] who had maximum cytological benign cases in the age groups 15-44 years and14-40 years respectively. Macintosh et al.,[14] had majority of benign cases in the age group 27-77 years. Maximum atypical category lesions were seen in the age group 31-68 years in thepresent study, while other studies do not mention this category in their study. In the presentstudy, cytological suspicious lesions were most common in the age group 33-72 years almost similar findings have been reported by Macintosh et al.,[14] and Rocha et al.,[7] who reportedmaximum number of suspicious cases in the age groups 33-75 years and 31-75 years,respectively. Malignant lesions were common in the age groups 35-77 years in the presentstudy, 35-84 years in the study by Khemka et al.,[13], 63-79 years in the study by Macintosh et al.,[14] and 41-75 years in the study by Rocha et al.,[7]. Unsatisfactory lesions were common in theage groups 19-55 years in the present study and 1450 years in the study by Rocha et al.,[7].Sooverall pattern of occurrence is as expected with benign lesions are seen in younger age groupand suspicious and malignant in older age group.In the present study, both sides (right and left) were not equally involved by the different types of cytological lesions. This is in association with the findings of Reddy and 
Reddy[15] and Clegg-Lamptey and Hodasi[16] in which the left side was slightly more common. Upper and outer quadrant was the most commonly involved quadrant $(31.48 \%)$ in the present study. This is in agreement with the findings of other studies like Rocha et al.[7] (45.20\%), Zuk et al.,[11] (42.20\%), Reddy and Reddy [15] (54.20\%), and CleggLamptey and Hodasi[16] (42.40\%). The exact cause of this finding is not known. In the present study, more benign cases and less malignant were seencytomorphologically like studies by Mohammed et al.,[4] Kim et al.,[17] Park and Ham[6] and Choi et al.,[18].This higher number of benign and lower number of malignant cases in other studies may be due to good follow up or more awareness amongst the patients. During aspiration, we found 9 of 50 breast carcinoma patients with palpable lymph nodes, 3 of them showed features of metastaticduct cell carcinoma and others were reactive nodes.This compared with Khan et al.,[19] had noticed more number of cases.Cytomorphologically sometimes, lobular carcinoma can appear as poorly differentiated carcinoma, as no pattern is seen. Sometimes, mastitis cases can be confused with IDC. This may be because, in the background to heavy inflammation, few cells may appear more atypical. The exact cause of poor cellularity in some benign or, malignant cases cannot be determined. The findings of DeyandLuthra et al.,[20] indicate that the presence of associated fibrocystic disease may be misleading because it can mask a malignancy. Hypocellularity and relatively mild nuclear atypia are the most common reasons for failure to diagnose a malignant breast lesion. In these cases careful attention to extreme nuclear pleomorphism and absence of naked bipolar cells along with radiologic suspicion should suggest a diagnosis of malignancy [21, 22]. In this study, we have realized that one cannot overlook the importance of clinical and radiological assessment for diagnosing breast lumps. This is especially so in cases that is labeled on cytology as atypical or suspicious. In such conditions, triple assessment (which assigns a score to a breast lesion by taking into consideration the clinical diagnosis, mammography diagnosis and the cytology diagnosis together and not any one diagnosis in isolation) is must. Triple test is particularly beneficial in a false negative scenario, in which the clinical decision to undertake a biopsy is usually based on index of suspicion and radiological imaging.

\section{Conclusion}

Fine-needle aspiration cytology is a rapid and effective method for the primary categorization of palpable breast lumps into benign, malignant, atypical, suspicious, and unsatisfactory categories. Benign breast lesions are common than malignant lesions, fibroadenoma and fibrocystic disease are more common in benign disease, whereas IDC accounts for the highest number of malignant lesions. Diagnostic accuracy of the procedure for malignant lesions is well established. More over FNAC can be repeated in cases of suspicious diagnosis or inadequate smear, further cases can be followed with biopsy for further confirmation. Due to rapid diagnosis we can reduce morbidity or mortality due to breast cancer and prevent further complications. Thus it is proved that early detection by FNAC and prompt management helps in reducing the morbidity and restricting the disease progression at the very initial stage. It also avoids unnecessary surgical intervention.

\section{Funding: Nil}

Conflict of interest: None.

Permission of IRB: Yes

\section{References}

1. Parkin DM, Bray F, Ferlay J, Pisani

P.Estimating the world cancer burden: Globocan 2000.I nt J Cancer. 2001 Oct 15;94(2):153-6.
2. Chopra R. The Indian scene.J ClinOncol.2001; 19:106-11. [PubMed]

3. Meena SP, Hemrajani DK, Joshi N.A comparative and evaluative study of cytological and histological grading system profile in malignant neoplasm of breast-an important prognostic factor.Indian J PatholMicrobiol. 2006 Apr;49(2):199-202.

4. Mohammed AZ, Edino ST, Ochicha O, Alhassan SU. Value of fine needle aspiration biopsy in preoperative diagnosis of palpable breast lumps in resource-poor countries: A Nigerianexperience. Ann Afr Med. 2005; 4:19-22.

5. Yeoh GP, Chan KW.Fine needle aspiration of breast masses: an analysis of 1533 cases in private practice.Hong Kong Med J. 1998 Sep;4(3):283-288.

6.Park IA, Ham EK.Fine needle aspiration cytology of palpable breast lesions.Histologic subtype in false negative cases.ActaCytol. 1997 JulAug;41(4):1131-8.

7. Rocha PD, Nadkarni NS, Menezes S.Fine needle aspiration biopsy of breast lesions and histopathologic correlation.An analysis of 837 cases in four years.ActaCytol. 1997 May-Jun;41(3):705-12. 
8. Domínguez F, Riera JR, Tojo S, Junco P.Fine needle aspiration of breast masses.An analysis of 1,398 patients in a community hospital.ActaCytol. 1997 MarApr;41(2):341-7.

9. Tiwari M.Role of fine needle aspiration cytology in diagnosis of breast lumps.Kathmandu Univ Med J (KUMJ). 2007 Apr-Jun;5(2):215-7.

10. Qasim M, Ali J, Akbar SA, Mustafa S. Lump breast: Role of FNAC in diagnosis. Prof Med J.2009; 16:2358 .

11. Zuk JA, Maudsley G, Zakhour HD.Rapid reporting on fine needle aspiration of breast lumps in outpatients.J ClinPathol. 1989 Sep;42(9):906-11

12. Tabbara SO, Frost AR, Stoler MH, Sneige $\mathrm{N}$, Sidawy MK.Changing trends in breast fine-needle aspiration: results of the Papanicolaou Society of Cytopathology Survey.Dia gnCytopathol. $2000 \mathrm{Feb}$;22(2):126-30.

13. Khemka A, Chakrabarti N, Shah S, Patel V. Palpable breast lumps: Fine-needle aspirationcytology versus histopathology: A correlation of diagnostic accuracy. Internet J Surg. 2009; 18:1.

$\begin{array}{lcr}\text { 14. MacIntosh } & \text { RF, Merrimen } & \text { JL, Barnes } \\ \text { PJ.Application of } & \text { the probabilistic approach to } \\ \text { reporting breast fine } & \text { needle } & \text { aspiration in } \\ \text { males.ActaCytol. 2008 Sep-Oct;52(5):530-4. }\end{array}$

15. Reddy DG, Reddy CR.Carcinoma of the breast, its incidence and histological variants among South Indians.Indian J Med Sci. 1958 Apr;12(4):228-34.

16. Clegg-Lamptey J, Hodasi W. A study of breast cancer in korlebu teaching hospital: Assessingthe impact of health education. Ghana Med J. 2007; 41:727. [PMC free article] [PubMed]

17. Kim A, Lee J, Choi JS, Won NH, Koo BH.Fine needle aspiration cytology of the breast. Experience at an outpatient breast clinic.ActaCytol. $2000 \quad$ MayJun;44(3):361-7.

18. Choi YD, Choi YH, Lee JH, Nam JH, Juhng SW, Choi C.Analysis of fine needle aspiration cytology of the breast: a review of 1,297 cases and correlation with histologicd iagnoses.ActaCytol. 2004 Nov-Dec;48(6):801-6.

19. Khan N, Rana F, Afroz N, Khan MA.Cytohistomorphological grading of breast carcinoma with special reference to apoptotic rates and lymph node metastasis.Indian J PatholMicrobiol. 2007 Jul;50(3):613-8.

20. Dey P, Luthra UK, Prasad A, Sheikh ZA, George SS.Cytologic grading and DNA image cytometry of breast carcinoma on fine needle aspiration cytology smears.Anal Quant CytolHistol. 1999 Feb;21(1):17-20.

21. Sankaye S, Kachewar S. Pathological panorama of Breast Cysts. Med J.2014; 39(3);458-463.

22. Kocjan G, Bourgain C, Fassina A, Hagmar B, Herbert A, Kapila K, Kardum-Skelin I, KlobovesPrevodnik V, Krishnamurthy S, Koutselini H, Majak B, OlszewskiW,Onal B, Pohar-Marinsek Z, Shabalova I, Smith J, Tani E, Vielh P, Wiener H, Schenck U, Schmitt F.The role of breast FNAC in diagnosis and clinical management: a survey of current practice.Cytopathology. 2008 Oct;19(5):271-8. doi: 10.1111/j.1365-2303.2008.00610.x.

\section{How to cite this article?}

VenkataramanaBabu p, Neeraja M, Varalakshmi K.P, SivasankaraNaik V, Sumankumar T.C.S., Cytomorphological study of palpable Breast Lumps by FNAC. Int J Med Res Rev 2016;4(2):238-244. doi: 10.17511/ijmrr.2016.102.019. 